\title{
SPRAY DRIFT AND PEST CONTROL FROM AERIAL APPLICATIONS ON SOYBEANS
}

Doi:http://dx.doi.org/10.1590/1809-4430-Eng.Agric.v37n3p493-501/2017

\section{JOÃO P. A. R. DA CUNHA ${ }^{1 *}$, ROBSON R. M. BARIZON ${ }^{2}$, VERA L. FERRACINI ${ }^{2}$, MARCIA R. ASSALIN ${ }^{2}$, ULISSES R. ANTUNIASSI ${ }^{3}$}

$1^{*}$ Corresponding author. Universidade Federal de Uberlândia/ Uberlândia - MG, Brasil. E-mail: jpcunha@ufu.br

\begin{abstract}
Pesticide drift is an issue in modern farming, mainly for crops under constant spraying as soybeans. This study aimed at assessing drift and pest control for aerial applications in soybean crops. Hydraulic nozzles and rotary atomizers, regulated to a wide spectrum of droplet sizes, sprayed thiamethoxam plus lambda-cyhalothrin using an agricultural aircraft Ipanema 202A at volume rate of $20 \mathrm{~L} \mathrm{ha}^{-1}$. Treatments consisted of testing two devices: a rotary cage atomizer (Micronair AU 5000) with blade angles of $65^{\circ}$ for larger droplets, and with angle of $55^{\circ}$ for smaller ones; and a set of adjustable nozzles (Stol model) with deflector angle of $90^{\circ}$ for smaller droplets, and with angle of $30^{\circ}$ for larger ones. Drift was evaluated through quantification of active ingredient, by means of liquid chromatography, on nylon strings set 20,40, 80, 160 and $320 \mathrm{~m}$ downwind from the applied area. Control efficiency was measured by counting caterpillars and stinkbugs found five days after spray. Rotary atomizers produced lesser drift compared to adjustable nozzles at the designed setting. Furthermore, drift can be reduced through a suitable regulation of the devices, keeping an effective pest control.
\end{abstract}

KEY WORDS: agricultural aviation, crop protection, exodrift, glycine max.

\section{INTRODUCTION}

Chemical control of insects in soybeans (Glycine max L. Merrill) is a very common farming practice, mainly against caterpillars and stinkbugs. If no performed, major losses of yield are expected (AITA et al., 2015). In this sense, most attention is given to which chemical to be used rather than to the way it is applied (BUENO et al., 2011).

For the operation to succeed, a proper spraying should be mastered, ensuring product reach to the target efficiently, lowering losses and environmental contamination. Part of the applied product can be lost, especially if application techniques are being wrongly used, constituting one of the largest challenges to be overcome in modern agriculture (NUYTTENS et al., 2011; ZHAO et al., 2014).

This issue can be observed in aerial application, which is a reality in great part of grain producing areas for Brazil. Such technique has been increasing a lot lately, however, little scientific information is found regarding its effectiveness, primarily in comparison to ground boom sprayers (CUNHA et al., 2014). For ANTUNIASSI et al. (2011), the main devices for droplet generation in aircrafts are rotary atomizers and hydraulic nozzles. They provide different droplet spectra, which in turn promotes different patterns of deposition and drift.

In some countries, particularly in Europe, one of the solutions to reduce drift has been to set safety zones (buffer zones), determined from drift simulations associated to toxicological studies. These areas are vegetation strips deprived from pesticide spraying, to prevent contamination of particular sensitive areas as watercourses and inhabitable regions (ALVES et al., 2014).

Notwithstanding, the length of this lane is variable and depends on spray conditions (DE SCHAMPHELEIRE et al., 2007). Therefore, studies measuring the horizontal distance a drop can

\footnotetext{
${ }^{2}$ Embrapa Meio Ambiente/ Jaguariúna - SP, Brasil.

${ }^{3}$ Universidade Estadual Paulista/ Botucatu - SP, Brasil.

Received in: 10-10-2016

Accepted in: 10-27-2016
} 
travel under several operational conditions are required to state the proper extent of these buffer zones, increasing both control efficiency and environmental safety.

Despite the environmental risk, few studies have been evaluating the drift in aerial application, especially in Brazilian conditions. Thus, this research aimed at evaluating drift and chemical control from aerial application of insecticides on soybeans, comparing rotary atomizers and adjustable hydraulic nozzles set to provide various droplet sizes.

\section{MATERIAL AND METHODS}

The research was carried out in a commercial grain producing area (2014-2015 season) in Monte Alegre de Minas, Minas Gerais state, in Brazil (18 $52^{\prime} \mathrm{S}$ latitude and $48^{\circ} 52^{\prime} \mathrm{W}$ longitude).

Soybean seeds, of P98Y70 RR Pioneer late-cycle cultivar, were sown at spacing of $0.5 \mathrm{~m}$ between rows with 10 plants per meter. The experiment consisted of four treatments as shown in Table 1, plus four replications. These treatments were composed of two application devices sprayed by aircraft, assessing pesticide drift and efficiency to control caterpillars and stinkbugs. In both devices, it was performed two scenarios, one accounting for the worst conditions in terms of drift risk (small droplets) and another for drift reduction (large droplets).

TABLE 1. Description of the experimental treatments.

\begin{tabular}{cccc}
\hline Treatment & Application device & Settings & Adjustment target \\
\hline 1 & Rotary atomizer & Blades at $55^{\circ}$ & Smaller size droplets \\
2 & Rotary atomizer & Blades at $65^{\circ}$ & Larger size droplets \\
3 & Hydraulic nozzle & Deflector at $90^{\circ}$ & Smaller size droplets \\
4 & Hydraulic nozzle & Deflector at $30^{\circ}$ & Larger size droplets \\
\hline
\end{tabular}

Sprays were carried out at R5.3 (beginning seed) when leaf area index was of 2.05, which was measured by the average of leaf areas sampled at four points of $1 \mathrm{~m}^{2}$.

All sprays were performed through an aircraft Ipanema EMB 202A, which was equipped with DGPS system, operating at $177 \mathrm{~km} \mathrm{~h}^{-1}(110 \mathrm{mph})$, flying three meters above the canopy, $16 \mathrm{~m}$ swath width and $20 \mathrm{~L} \mathrm{ha}^{-1}$ application volume rate.

In atomizer treatments, six rotary cage atomizers (Micronair ${ }^{\circledR}$ AU 5000) were set with blades angled at $65^{\circ}$, for larger droplets, and at $55^{\circ}$, for smaller ones. The system pressure was at $193 \mathrm{kPa}$. In the another treatments, 54 hydraulic adjustable nozzles (Stol ${ }^{\circledR}$ model) were set with deflector at $90^{\circ}$, for smaller diameters, and at $30^{\circ}$, for larger ones, according to each treatment, and orifice size D6. In this case, pressure was set at $138 \mathrm{kPa}$.

According to the manufacturer of Micronair AU5000, blades at the angles of $65^{\circ}$ and $55^{\circ}$ promote a fine droplet spectrum, with volume median diameters (VMDs) of 203 and $142 \mu \mathrm{m}$, respectively, as classified by ASABE (ASABE, 2009). On the other hand, the manufacturer provide no information of droplet sizes for the adjustable nozzles, so the field conditions (flow rate and air speed) was simulated through a wind tunnel (NEMPA, FCA/UNESP, Botucatu-SP, Brazil) testing, measuring the droplet size by means of an droplet analyzer, in real time, based on the analysis of high resolution images. For that, it was used VisiSize D30 equipment (Oxford Lasers Imaging Division, England). Therefore, with deflector positioned at $90^{\circ}$ and $30^{\circ}$, the set of nozzles generated a fine droplet spectrum with VMDs of 156 and $194 \mu \mathrm{m}$, respectively.

Experimental plots were $250 \mathrm{~m}$ long and $128 \mathrm{~m}$ wide. The aircraft passed over the target area eight times within a $16 \mathrm{~m}$ swath width to ensure a proper overlapping, with crosswind towards the line of application.

Spraying solution was composed of an insecticide combination of thiamethoxam $\left(141 \mathrm{~g} \mathrm{~L}^{-1}\right)$ and lambda cyhalothrin $\left(106 \mathrm{~g} \mathrm{~L}^{-1}\right)$ - Engeo Pleno ${ }^{\circledR}$, at a dose of $200 \mathrm{~mL} \mathrm{ha}^{-1}$, plus vegetable oil $\left(\right.$ Veget'oil $^{\circledR}$ - fatty acid esters $-930 \mathrm{~g} \mathrm{~L}^{-1}$ ), at a dose of $300 \mathrm{~mL} \mathrm{ha}^{-1}$. 
For drift evaluation, collectors were previously set; these devices were made of PVC structures with a 2-mm nylon strings extended for $2 \mathrm{~m}$ vertically. These collectors were placed at 20, 40, 80, 160 and $320 \mathrm{~m}$ downwind from application area, counted from the borderline of each plot, making four replications for each. They were all set so that each monofilament was promptly above crop canopy.

Therefore, drift was assessed by quantification of the amount of thiamethoxam active ingredient on strings analyzed by means of liquid chromatography. To this end, nylon strands were carefully gathered shortly after application, to avoid cross-contamination, and placed into plastic bags under no light, being subsequently sent for analysis in the Laboratory of Pesticide Residues, which belongs to the Embrapa Environment, located in the city of Jaguariúna-SP, Brazil.

The samples were then cut into pieces of nearly $0.5 \mathrm{~cm}$ using pliers; then, a $5 \mathrm{~g}$ sample was weighed in a $125 \mathrm{~mL}$ Erlenmeyer flask. Next, $10 \mathrm{~mL}$ methanol was added and stirred for $48 \mathrm{~h}$ using a shaking table at $65 \mathrm{rpm}$ and at room temperature. An aliquot of $1 \mathrm{~mL}$ was pipetted and filtered directly into a filtering unit (PVDF - Hydrophilic, $0.22 \mu \mathrm{m}$ ). Separations were made through a highperformance liquid chromatography (Shimadzu, Japan), consisting of a pumping system (LC 10 AT VP), auto-sampler (SIL 120 A), column oven (CTO 10A) and detection by UV-VIS (SPD 10 AV vp) at a wavelength of $254 \mathrm{~nm}$. It was used a $5-\mu \mathrm{C} 18$ column $(250 \times 4.6 \mathrm{~mm})$, at $0.6 \mathrm{~mL} \mathrm{~min}^{-1} \mathrm{flow}$ rate, gradient elution mode, water-acetonitrile as mobile phase, starting at $10 \%$ acetonitrile, which was increased linearly up to $40 \%$, during 20 minutes, keeping it for a minute, thus totaling a 30 minute run. Injection volume was of $20 \mu \mathrm{L}$. The thiamethoxam retention time was 20.4 minutes. Quantitation testing was performed using an analytical curve of six different concentrations (from 0.0025 to $0.2500 \mu \mathrm{g} \mathrm{mL}^{-1}$ ).

Once the amount of active ingredient per collector area was taken, drift index was estimated as function of thiamethoxam volume sprayed per area $\left(28.2 \mathrm{~g} \mathrm{ha}^{-1}\right)$.

$$
\text { Drift index }=\frac{\beta_{\text {dep }} \times 10000 \mathrm{~m}^{2} \mathrm{ha}^{-1}}{\beta_{\mathrm{v}}}
$$

In which,

Drift index - relative drift index (dimensionless);

$\beta_{\mathrm{dep}}-$ deposited drift $\left(\mu \mathrm{g} \mathrm{cm}^{-2}\right)$, and

$\beta_{\mathrm{v}}-\operatorname{dose}\left(\mathrm{g} \mathrm{ha}^{-1}\right)$.

Treatment control efficiency against caterpillars (Anticarsia gemmatalis and Pseudoplusia includens) and stinkbugs (Euschistus heros, Nezara viridula and Scaptocoris castanea) was evaluated in two times, before and five days after spraying. To do so, five random sampling points were selected within each plot $\left(6,400 \mathrm{~m}^{2}\right)$, from where individuals were collected with the aid of a beat cloth $(1.0 \times 0.5 \mathrm{~m})$ and counted. From the number of collected insects, control efficiency could be calculated using the Abbott's formula (ABBOTT, 1925).

During sprayings, environmental conditions were monitored as temperature, air relative humidity, wind speed and direction by means of a fully automatic weather station.

Data were compared by the confidence intervals for differences between means, at confidence level of $90 \%$ (90\% CI), as described by ANTUNIASSI et al. (2011).

As already performed by HOFFMANN \& KIRK (2005), field data were compared to simulations from a drift prediction software - AgDrift ${ }^{\circledR}$ (Spray Drift Task Force Spray Software, version 2.1.1), for each treatment (Table 1). This computer program takes account of climate conditions and has a specific module of drift simulation for aircraft spraying (TESKE et al., 2002), with an extensive database. However, it should be highlighted that Ipanema aircraft models were not assessed, especially regarding the winglet. Moreover, the software keeps a database of the 
AU5000 atomizer, but not of the hydraulic nozzles of Stol brand. Thereby, it was selected an adjustable nozzle with great similarity: CP-03 (CP Products, Texas, USA).

The correlation between observed and predicted values was made by the Pearson's method, at 0.05 significance level. Regression lines of each treatment were compared to 1-1 lines. The F-test, at 0.05 significance level, was used to test the hypothesis of intercept linear values and slope coefficient being equal to 0 and 1, respectively. For that, it was used the R software (version 2.9.2).

\section{RESULTS AND DISCUSSION}

During the applications, temperature, relative humidity and wind speed raised from 23.9 to $25.3^{\circ} \mathrm{C}$, from 74 to $81 \%$ and from 5.8 to $7.3 \mathrm{~km} \mathrm{~h}^{-1}$, respectively. In brief, these variations whilst performing were low. Notwithstanding, this information is important since, among all factors interfering with pesticide drifting, environmental and weather conditions (temperature, air humidity and wind speed) are the most impacting (ARVIDSSON, 2011; HILZ \& VERMEER, 2013; GIL et al., 2014).

Figure 1 displays a graphic of drift index up to $320 \mathrm{~m}$ far from target area. Based on this, it is noteworthy that treatments were difference, mainly within the shortest distances. Nozzles adjusted for small droplets (deflector at $90^{\circ}$ ) generated the largest drift values, reaching a relative drift of 0.728 at $20 \mathrm{~m}$ away, being followed by deflector at $30^{\circ}(0.314)$. Therefore, a simple exchange of deflector angle from 90 to $30^{\circ}$ would reduce drift, decreasing risks in 57\%. Still, atomizers achieved lower values of drift compared to hydraulic nozzles, without differing from one to another, and showing mean drift index of 0.062 ( $91.5 \%$ reduction with regards to the worst case).

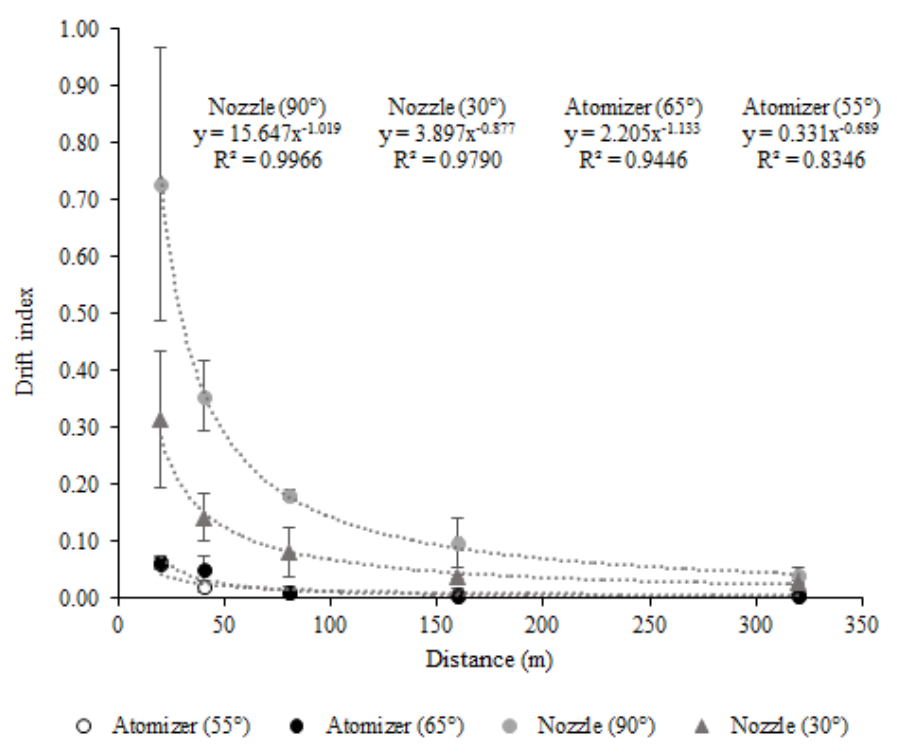

FIGURE 1. Drift curves for aerial application of thiamethoxam using rotary atomizer with blades at $55^{\circ}$ and $65^{\circ}$, and hydraulic nozzles with deflector at $90^{\circ}$ and $30^{\circ}$. Vertical bars stand for the confidence interval $(90 \%)$.

In summary, it was possible to infer that atomizers are most interesting tools to reduce drift when matched to adjustable nozzles. In a similar study, HEWITT et al. (1994) simulated aerial spraying by a wind tunnel and observed atomizers had a uniform droplet spectrum, decreasing thus the amount of very fine droplets, more likely to drifting.

In this sense, HOFFMANN \& KIRK (2005) demonstrated that two different spray nozzles classified as medium droplets, had varying drift behaviors. Adjustable nozzles, placed $50 \mathrm{~m}$ apart from target, had drift values 3.2 times larger than other nozzles as discs and cores. Overall, it confirms the point of a particular constructive design for each spray system on drift behavior. 
Drift comparative assessments between atomizers and hydraulic nozzles are quite uncommon in literature. Notwithstanding, a few studies have suggested atomizers to have a better performance relative to the nozzles (CALDWELL, 2006). This author noted that rotary atomizers promote lower drift, although the VMD $(213 \mu \mathrm{m})$ was slightly lower than those using hydraulic nozzles $(283 \mu \mathrm{m})$. The same research also highlights that other characteristics such as nozzles and atomizers arrangement along the aircraft spray boom, can also interfere with the drift results besides droplet spectrum.

The largest drift rates were observed at sampling points quite near the crop, decreasing as it moved away from the treated area. Drift curves with this profile had already been found by other authors, such as HOFFMANN \& KIRK (2005) and ANTUNIASSI et al. (2014).

When evaluating the distances of 40 and $80 \mathrm{~m}$, drift showed a similar behavior, in which nozzles with deflector at $90^{\circ}$ reached the largest values $(0.355)$, followed by those with deflector at $30^{\circ}(0.143)$, reducing at $59.7 \%$, just by angle adjustment. Whereas atomizers achieved a value of 0.036 , being $89.9 \%$ lower than the first case. Once again, angle adjustment of blades had no effect on results.

From $160 \mathrm{~m}$ downwind, the differences between treatments tended to decrease with distance. For this reason, it was detailed that region of drift curve (Figure 2). In addition, again at $160 \mathrm{~m}$, it was observed the highest drift index for nozzles set at $90^{\circ}(0.098)$, followed by those at $30^{\circ}(0.038)$, showing a reduction of $61.2 \%$, while atomizers had no difference among the blade angles, reaching an index of 0.007 (92.9\% reduction).

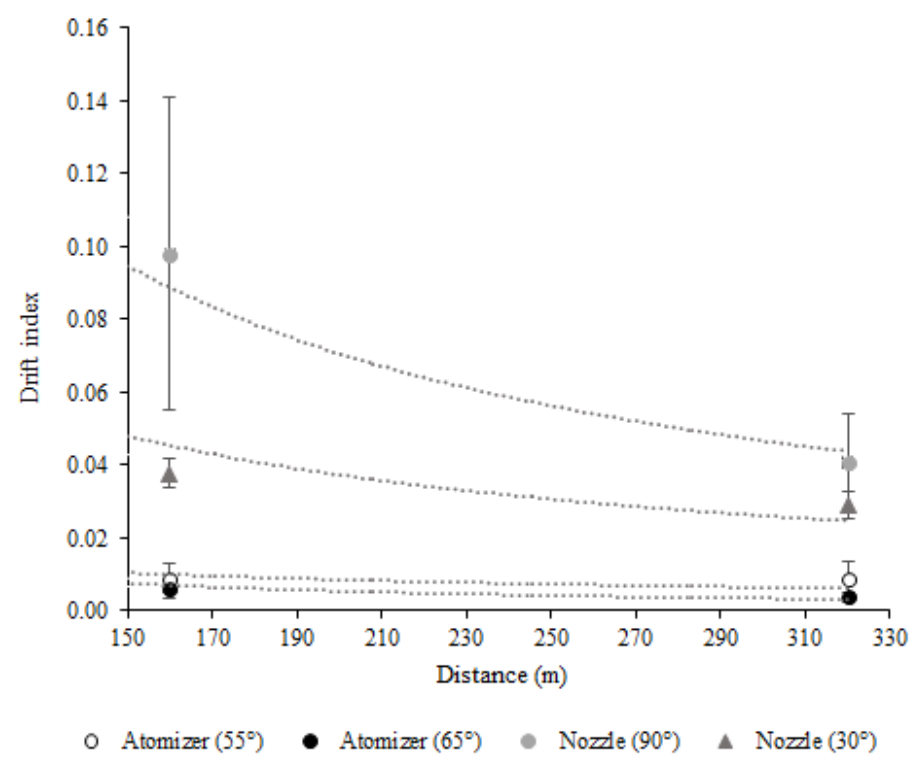

FIGURE 2. Detailed drift curves for aerial application of thiamethoxam using rotary atomizer with blades at $55^{\circ}$ and $65^{\circ}$, and hydraulic nozzles with deflector at $90^{\circ}$ and $30^{\circ}$. Vertical bars stand for the confidence interval $(90 \%)$.

When considering the longest distance $(320 \mathrm{~m})$, the settings of the nozzles had no effect on drift. MOKEBA et al. (1998) stated that when droplets stop accelerating (i.e., when they travel the same speed as the surrounding air), their dispersal becomes controlled by random turbulence effects or air currents. Applications with atomizers promoted less drift (0.009) whether compared to adjustable nozzles (0.044), i.e. an average reduction of 79.6\%. Nonetheless, in this study, it was not made an extensive investigation of drift reduction techniques under different operating conditions. Even though it was possible to observe that drift can be reduced just by executing a few settings, future investigations are necessary to evaluate the arrangements of nozzles along sprayer boom, as well as the use of new drop atomizers and adjuvants to minimize losses by drift. 
Figure 1 have shown the drift curves designed with data gathered in field. By regression analysis, it must be pointed out that the equation of the power type had good fit to the data, although the $\mathrm{R}^{2}$ for treatments with nozzles was lower than with atomizers. This outcome might have been related to the difference between the observed and estimated values for the distance of $20 \mathrm{~m}$.

Regarding pest control efficiency (Figure 3), a lack of difference among treatments for both caterpillar and stinkbugs was observed. These results just reinforce the fact that using treatments that reduce losses by drift should be clearly chosen due to their technical feasibility, particularly those with atomizers. Considering all treatments, the numbers of insects per square meter, found five days after applications, were of 0.2 caterpillars and 0.4 stinkbugs. Prior to sprayings, it was found an average number of 3.0 caterpillars and 4.8 stinkbugs per square meter, therefore, control efficiency was of $93.3 \%$ and $91.7 \%$, respectively, which led to conclude that such insecticide has high efficiency $(>90 \%)$.

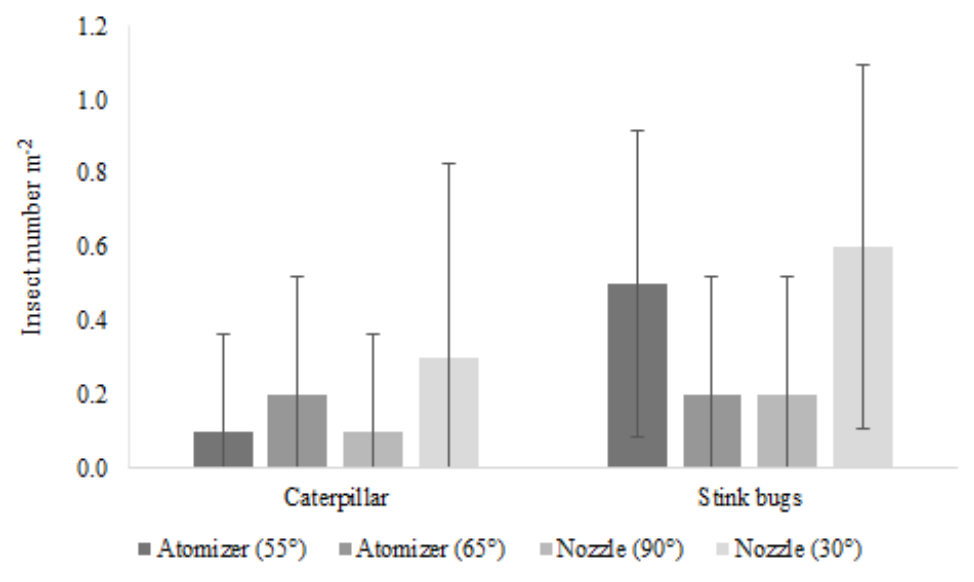

FIGURE 3. Numbers of caterpillars and stinkbugs five days after aerial application of thiamethoxam using rotary atomizer with blades at $55^{\circ}$ and $65^{\circ}$, and hydraulic nozzles with deflector at $90^{\circ}$ and $30^{\circ}$. Vertical bars stand for the confidence interval $(90 \%)$.

Drift values estimated by the AgDrift model were compared to those obtained experimentally, and all treatments showed a significant correlation between observed and simulated values (Pearson's correlation at $\mathrm{p}<0.05$ ). This correlation denotes that the model satisfactory simulated drift decay trend as function of distance.

To check if the model presented any bias for curve adjustments, both observed and simulated values were plotted onto a linearized graph (Figure 4). The closer the predicted values get to the 1-1 line, the better the model fit is. For rotary atomizers at $55^{\circ}$, simulated values were overestimated, once they were placed below the 1-1 line. It might have occurred because the aircraft winglet was not taken into consideration, which reduces the drift values. Likewise, HOFFMANN \& KIRK (2005) had also found conflicting results when comparing observed and simulated values. However, these authors claimed no explanation for such outcome. On the other hand, simulated values for hydraulic nozzle at $30^{\circ}$ and $90^{\circ}$ proved to have been underestimated, with all points positioned above the 1-1 line. Perhaps this may have occurred because the software has no specific database for this nozzle model. Droplet spectrum variations for each nozzle may lead to different drift value. 


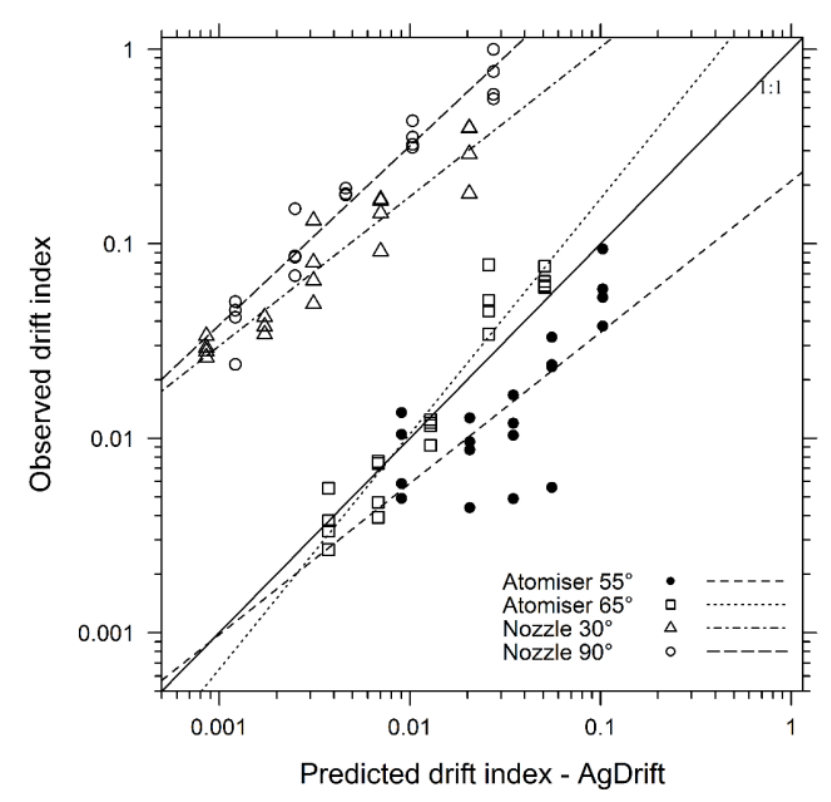

FIGURE 4. Thiamethoxam drift values by the use of rotary atomizer with blades at $55^{\circ}$ and $65^{\circ}$, and hydraulic nozzles with deflector at $90^{\circ}$ and $30^{\circ}$, both from field evaluations and simulated by AgDrift model.

When using atomizer at $65^{\circ}$, simulation was overestimated for low drift values and underestimated for large ones, i.e. the drift model overestimated drift at long distances and underestimated it for short ones. To confirm that trend lines adjusted for each treatment, in Figure 4, differ from the 1-1 line, observed and simulated linearized data underwent regression analysis, and the resulting equation was compared by hypothesis testing with the 1-1 line equation (intercept $=$ zero and slope coefficient $=1)$. The equations of all treatments differed significantly $(\mathrm{F}$-test, $\mathrm{p}<$ 0.05) from the one obtained for the 1-1 line, showing that the results generated by the AgDrift model did not satisfactorily express the experimental data.

Despite these differences, this software is sensitive to differentiate treatments, which in addition to the good fit of the drift curve as function of distance denote its potential to assess risks of drift from aerial application. In this regard, a database expansion, especially regarding regional data, could enhance its simulations.

\section{CONCLUSIONS}

Rotary atomizers showed the lowest levels of drift with high efficiency to control caterpillars and stinkbugs in soybeans, whether compared to the hydraulic adjustable nozzles.

It is possible to reduce drift in aerial applications by making proper adjustments. In this sense, further studies are required to broaden the number techniques to be used for drift reduction.

Computational simulation, by means of AgDrift software, showed sensitivity to estimate drift under different operating conditions, however, simulated values differed materially from those observed in field, so its database must be broadened to include diverse local conditions.

\section{ACKNOWLEDGEMENTS}

To Empresa Brasileira de Pesquisa Agropecuária (Embrapa), for financial support; to Algar Farming and Sindag for the support in the field evaluations; and to Ricardo Almeida Antônio Pazianotto for the support in data analysis. 


\section{REFERENCES}

ALVES, G.S.; CUNHA, J.P.A.R. Field data and prediction models of pesticide spray drift on coffee crop. Pesquisa Agropecuária Brasileira, Brasília, DF, v. 49, n. 8, p. 622-629, 2014. DOI: 10.1590/S0100-204X2014000800006

ABBOTT, W.S. A method of computing the effectiveness of an insecticide. Journal of Economic Entomology, Lanham, v. 18, p. 265-267, 1925.

AITA, V.; MAGANO, A.; MACHADO, M. R. R.; GUEDES, J. V. C. Manejo de lagartas na cultura da soja com aplicação de controle localizado. Interciência, Caracas, v. 40, n. 11, p. 784-788, 2015.

ANTUNIASSI, U.R.; MOTTA, A.A.B.; CHECHETTO, R.G.; CARVALHO, F.K.; VELINI, E.D.; CARBONARI, C.A. Spray drift from aerial application. Aspects of Applied Biology,

Wellesbourne, v. 122, p. 279-284, 2014.

ANTUNIASSI, U.R.; VELINI, E.D.; OLIVEIRA, R.B.; OLIVEIRA, M.A.P.; FIGUEIREDO, Z. Systems of aerial spraying for soybean rust control. Engenharia Agrícola, Jaboticabal, v. 31, n. 4, p. 695-703, 2011. DOI: 10.1590/S0100-69162011000400008. Disponível em:

<http://www.scileo,br/eagri>. Acesso em: 10 jul. 2016.

ARVIDSSON, T.; BERGSTRÖM, L.; KREUGER, J. Spray drift as influenced by meteorological and technical factors. Pest Management Science, New York, v. 67, n. 5, p. 586-598, 2011. DOI: $10.1002 /$ ps. 2114

ASABE - AMERICAN SOCIETY OF AGRICULTURAL AND BIOLOGICAL ENGINEERS. Spray nozzle classification by droplet spectra, ANSI/ASAE S572.1. St. Joseph, 2009. 4p.

BUENO, M.R.; CUNHA, J.P.A.R.; ALVES, G.S. Estudo do espectro de gotas produzidas nas pulverizações aérea e terrestre na cultura da batata. Revista de Ciências Agrárias, Belém, v. 54, n. 3, p. 225-234, 2011. DOI: 10.4322/rca.2012.018

CALDWELL, D.M. Quantification of spray drift from aerial applications of pesticide.

Saskatoon. 2006. 106f. Dissertação (Mestrado) - University of Saskatchewan, Saskatoon, 2006.

CUNHA, J.P.A.R.; JULIATTI, F.C.; REIS, E.F. Tecnologia de aplicação de fungicida no controle da ferrugem asiática da soja: resultados de oito anos de estudos em Minas Gerais e Goiás.

Bioscience Journal, Uberlândia, v. 30, n. 4, p. 950-957, 2014. Disponível em:

<http://www.seer.ufu.br/index.php/biosciencejournal/indexi>. Acesso em: 10 jul. 2016.

DE SCHAMPHELEIRE, M.; SPANOGHE, P.; SONCKC, S. Risk assessment of pesticide spray drift damage in Belgium. Crop Protection, Madison, v. 26, n. 4, p. 602-11, 2007. DOI:

10.1016/j.cropro.2006.05.013

GIL, E.; BALSARI, P.; GALLART, M.; LLORENS, J.; MARUCCO, P.; ANDERSEN, P.G.;

FÀBREGAS, X.; LLOP, J. Determination of drift potential of different flat fan nozzles on a boom sprayer using a test bench. Crop Protection, Madison, v. 56, p. 58-68, 2014. DOI:

10.1016/j.cropro.2013.10.018

HEWITT, A.; ROBINSON, A.G.; SANDERSON, R.; HUDDLESTON, E.W. Comparison of the droplet size spectra produced by rotary atomizers and hydraulic nozzles under simulated aerial application conditions. Journal of Environmental Science and Health Part B, Abingdon, v. 29, n. 4, p. 647-660, 1994.

HILZ, E.; VERMEER, A.W.P. Spray drift review: the extent to which a formulation can contribute to spray drift reduction. Crop Protection, Madison, v. 44, p. 75-83, 2013. DOI:

10.1016/j.cropro.2012.10.020

HOFFMANN, W.C.; KIRK, I.W. Spray deposition and drift from two medium nozzles.

Transactions of the Asae, St Joseph, v. 48, n. 1, p. 5-11, 2005. 
MOKEBA, M. L.; SALT, D. W.; LEE, B. E.; FORD, M. G. Computer modeling of the meteorological and spraying parameters that influence the aerial dispersion of agrochemical sprays. International Journal of Biometeorology, Amsterdam, v. 41, n. 4, p. 194-199, 1998.

NUYTTENS, D.; DE SCHAMPHELEIRE, M.; BAETENS, K.; BRUSSELMAN, E.; DEKEYSER, D.; VERBOVEN, P. Drift from field crop sprayers using an integrated approach: results of a fiveyear study. Transactions of the ASABE, St Joseph, v. 54, n. 2, p. 403-408, 2011.

TESKE, M. E.; BIRD, S. L.; ESTERLY, D. M.; CURBISLEY, T. B.; RAY, S. L.; PERRY, S. G. AgDrift ${ }^{\circledR}$ : A model for estimating near-field spray drift from aerial applications. Environmental Toxicology and Chemistry, New York, v. 21, n. 3, p. 659-671, 2002.

ZHAO, H.; XIE, C.; LIU, F.; HE, X.; ZHANG, J.; SONG, J. Effects of sprayers and nozzles on spray drift and terminal residues of imidacloprid on wheat. Crop Protection, Oxford, v. 60, p. 7882, 2014. DOI: 10.1016/j.cropro.2014.02.009 